\title{
PHYSIOLOGICAL QUALITY AND AFLATOXIN PRESENCE IN WHEAT SEEDS TREATED WITH FUNGICIDES AND ADJUVANTS DURING CROP DEVELOPMENT
}

\author{
QUALIDADE FISIOLÓGICA E PRESENÇA DE AFLATOXINAS EM SEMENTES DE \\ TRIGO TRATADAS COM FUNGICIDAS E ADJUVANTES DURANTE O \\ DESENVOLVIMENTO DA CULTURA
}

\author{
Lúcia Helena Pereira NÓBREGA; Michelle TONINI²; Cristiane Lurdes PALOSCHI³; \\ Walter BOLLER ${ }^{4}$; Adriana Maria MENEGHETTI ${ }^{5}$; Joseli Viviane Ditzel NUNES ${ }^{2}$ \\ 1.Engineering Agronomist, Assistant Professor - Postgraduation in Agricultural Engineering, Western Paraná State \\ University (UNIOESTE), Cascavel, PR, Brazil. Corresponding author: lucia.nobrega@ unioeste.br. 2. PhD - Postgraduation in \\ Agricultural Engineering - UNIOESTE - Brazil. 3. Postgraduation in Agricultural Engineering Student - UNIOESTE - Brazil. 4. \\ Engineering Agronomist, PhD Professor - Passo Fundo University, Undergraduate and postgraduate course in Agronomy and Veterinary \\ Medicine, Passo Fundo, PR, Brazil. 5. Chemistry Bachelor Degree - Federal Technological University of Paraná - Bachelor Degree in \\ Biological Sciences. Chemistry area. Santa Helena - PR -Brazil.
}

\begin{abstract}
Wheat (Triticum aestivum L.) is a cereal with great economic importance and yield capacity. However, it can be attacked by various diseases, which require the use of fungicides during crop development. Thus, this study aimed to evaluate the physiological quality of wheat seeds when treated with fungicides concentrations during crop development. Plants of Mirante variety were cropped with foliar application of fungicides with active ingredients strobilurin and triazole plus foliar adjuvant. After harvesting, the seeds moisture content, germination percentage, accelerated aging, controlled deterioration, cold test, sand emergence, electrical conductivity and aflatoxins presence were evaluated. The obtained results showed that physiological quality and aflatoxin presence in wheat seeds were not influenced when the studied fungicides were used. The seeds showed high seedling germination index, even when submitted to stressful conditions.
\end{abstract}

KEYWORDS: Foliar application. Germination, Triticum aestivum L. Vigor.

\section{INTRODUCTION}

Wheat (Triticum aestivum L.) has a great economic importance among the cold climate cereals. It is cropped under the most varied environmental conditions, with large grain yield capacity, nutritional quality and high degree of adaptability (MARINI et al., 2011).

In Brazil, wheat yield increase has an economic interest, because in addition to meeting the demand, its cropping improves soil conditions and provides waste for summer crops, such as soybeans and maize (BARBIERI et al., 2013).

Due to the great consumption, high physiological quality of wheat seeds is very important because it increases productivity and results in lower yield costs. According to Mielezrski et al. (2008), high seed vigor originated plants with higher physiological potential, which is reflected in higher growth and yield.

However, in order to obtain good conditions during wheat cropping, diseases control should be performed since its beginning. The diseases management guarantees the best seeds physiological potential. Most diseases that attack wheat are transmitted by seeds, which can cause reduction in vigor and germination. According to Peske et al. (2006), seeds infected by pathogens may not show viability or present low vigor. Seeds are a pathogen vehicle, which can sometimes cause disease outbreaks in crops because small amounts of inoculum may be of great epidemiological significance.

Wheat is very susceptible to fungal infection and mycotoxin contamination. This cereal é very cropped in Southern Brazil, whose region has a subtropical climate. The association of this kind of climate and the non-adoption of no-tillage systems may favor the onset of serious epidemics, cause serious problems in yield and reduce wheat quality (ASTOLFI et al., 2011).

Mycotoxin contamination of wheat results from fungal pathogens may during flowering, delayed harvest due to wet conditions, and in storage. Several species of Fusarium, Penicillium, and Alternaria may infect grain if the harvest is delayed due to wet conditions, and isolates of Aspergillus and Penicillium may infect during 
storage if there is sufficient moisture to support fungal growth (Jacobsen, 2014).

Seeds treatment, in general, is the application of processes and substances that preserve or refine the performance of themselves. It includes the application of pesticides (fungicides, insecticides), biological products, inoculants, etc. or submission to other physical processes. In a more specific sense, it refers to the application of effective chemicals against plant pathogens (MENTEN; MORAES, 2010).

For wheat, the presence of chemical contaminants such as pesticides and mycotoxins waste is not visualized in the final product and consequently it is one priority challenge in food production (EMBRAPA, 2013). Quality control is essential to ensure safe food consumption.

In countries with warmer climates, the aflatoxin contamination produced by Aspergillus spp (A. flavus, A. parasiticus, A. niger, $A$. ochraceus, A. oryzae, among other species) has often been identified at high levels for wheat and its by-products (AYDIN; GUNSEN; DEMIREL, 2008; GHALI et al., 2008; JOUBRANE et al., 2011). The regulation of the Ministry of Health $\left(\mathrm{RDC} \mathrm{N}^{\mathrm{o}}\right.$. 7, February $18^{\text {th }}, 2011$ ) recommends that permissible limits for mycotoxins in Brazil in wheat and its byproducts, are $5 \mu \mathrm{g} \mathrm{kg}^{-1}$ for the sum of aflatoxins B1 $+\mathrm{B} 2$ + G1 + G2 (BRASIL, 2011). Aflatoxin B1 (AFB1) is the most potent hepatocarcinogen known in mammals and is classified by the International Agency of Research on Cancer (IARC) as Group 1 carcinogen (INTERNATIONAL AGENCY FOR RESEARCH ON CANCER (IARC), 1993).

According to Neme and Mohammed (2017), mycotoxins are poisonous compounds produced by certain species of fungi found in contaminated grain. There are five major groups of mycotoxins which can occur in grains: Aflatoxin, fumonisin, deoxynivalenol (DON), ochratoxin (OT), and zearalenone $(\mathrm{ZEN})$. Their occurrence may start in the field, harvesting, handling, storage, and processing. DON, ZEN, and fumonisins may start to cause the grains at the field/or pre-harvest while aflatoxin and OT are mostly occurring during storage due to improper postharvest handling. Most of the grains susceptible to mycotoxins such as maize, peanut/groundnut, sorghum, millet, wheat, and rice were reviewed. The main postharvest factors for the cause of grain mycotoxin contamination are mechanical injury, insect infestation, time of harvesting, drying method, types of storage structure and conditions, handling and processing. Temperature, moisture and humidity are the main factors for the growth and development of mycotoxins.

The relationships among aflatoxin levels and humidity, storage temperature and storage duration of wheat and flour in two seasons showed significant association among the levels of aflatoxin G1, G2, B1, B2 and total aflatoxin with temperature and humidity of silos in summer. In winter, wheat and flour storage duration and aflatoxin G1 were significantly correlated. Aflatoxin B1 and total aflatoxin was significantly associated with humidity (TAHERI et al., 2012).

The same authors ((TAHERI et al., 2012)) mentioned that Basilico (1995) showed that fungal growth and toxin production were associated with fungi, host and environment that can influence the types and quantity of toxin produced by fungi. Also mentioned that it is known that the crop varieties, weather pattern, temperature, humidity, water activity, level of oxygen, poor storage condition, inadequate drying, activity of insects or rodents and other problems affect Aspergillus growth and aflatoxin production in storage products (O'BRAIN et al., 2007; COTTY; JAIME-GARCIA, 2007).

Due to the important role of aflatoxin contamination, especially negative effect of aflatoxin B1 on public health, efforts should be conduct to prevent it, since prevention is the most economical and practical approach. Controlling environmental factors such as storage duration, temperature and humidity can help with achieving this goal (TAHERI et al., 2012).

According to Trombete et al. (2014), in Brazil, there are few studies concerning the occurrence of aflatoxins in wheat and its byproducts. In other countries, such as Tunisia, Lebanon and Turkey, high levels of aflatoxins have been reported in wheat and by-products, which represent a health risk to consumers. The authors mentioned above verified that, from a total of 180 samples analyzed, $33(30.5 \%)$ were positive for at least one aflatoxin kind and just one sample (wheat grain) showed levels higher than the limit established by Brazilian legislation $\left(5 \mu \mathrm{g} \mathrm{kg}^{-1}\right)$. The contamination was the highest in the grain samples, followed by bran, whole-flour and refined flour. The studied levels have indicated that the presence of aflatoxins in wheat and by-products consumed in Rio de Janeiro, Brazil, is not hazard for public health.

Wheat is the most important cereal crop in terms of cropped area, production, and consumption in Iran. Owing to the abundant production and the main role of wheat and its flour products in human and animal diets. They can play a very important 
role in endangering human health in case of contamination with health-threatening factors. In this context, Razdari et al. (2014) verified that reducing aflatoxin contamination is possible by reducing wheat storage time and controlling humidity. Results have shown that there have been lots of mycotoxins with a level from 36.3 to 2.891 $\mathrm{mg} / \mathrm{g}$. This fact occurs due to the detrimental effect of the milling process. Thus, the prevention of their growth and contamination by decreasing temperature, humidity, treatment with pesticides are of great importance.

In recent years, there was a great register by researchers concerning mycotoxins presence in tropical regions. Therefore, the possibility of cereal crops contamination such as wheat, barley, rye, millet and their by-products is a result from direct contact with initial or environmental sources, even when grains are kept under high humid conditions, and consequently cause deterioration (RAZDARI et al., 2014).

Asghar et al (2016) studied the isolate fungal pathogens and to subsequently quantify aflatoxin (AF;B1 p B2 p G1 p G2) contamination in wheat crops grown in Pakistan. Accordingly, a total of 185 wheat samples were collected from different areas of Pakistan and numerous potent fungal pathogens were isolated. Additionally, the effect of fungal pathogens on seed germination was also examined. The results obtained showed that $50 \%$ of tested wheat samples were found to be contaminated with a diverse range of fungal species. The germination rate of wheat seeds was assessed using the standard blotter paper method. The fungal growth may not only change the chemical and physical properties of the food products but is also responsible for the deterioration of nutrient contents of the grains. The quality and germination rate of seeds is directly and indirectly affected by the seedborne pathogens.

Thus, this study aimed to verify physiological quality and aflatoxins presence in wheat seeds when treated with fungicides and adjuvants during this crop development.

\section{MATERIAL AND METHODS}

The samples were wheat seed produced in Passo Fundo, RS, Brazil, from July to November 2011 harvest in the experimental area of the Faculty of Agronomy and Veterinary. There is a $687 \mathrm{~m}$ altitude, humid temperate climate and average annual temperature between 12.7 and $22.1{ }^{\circ} \mathrm{C}$. Its minimum is in June and its maximum in January. The average rainfall is $1,788 \mathrm{~mm}$, with rainfall distributed throughout the year and temperatures near or below zero (EMBRAPA, 2013) in soil classified as OXISOL.

Sowing was under no-tillage system, with a density of 350 viable seeds $\mathrm{m}^{-2}$ in the first half of July, with maize as the preceding crop after desiccation with glyphosate herbicide. The desiccated pre-sowing was post-emergent herbicide paraquat contact (Gramoxone $®$ ) at $1.5 \mathrm{~L} \mathrm{~h}^{-1}$ dose.

The fertilizer was distributed along seeding rows with $250 \mathrm{~kg} \mathrm{ha}^{-1}$ fertilizer in 5-25-0 N-P-K formulation, according to soil analysis. Nitrogen application in coverage, with $45 \mathrm{~kg} \mathrm{ha}^{-1} \mathrm{~N}$ in the form of granulated urea, was carried out between the stadium of tillering and elongation, which corresponds to 30 and 45 days after emergence.

Mirante wheat variety was chosen by the productive potential in areas of average or high fertility, with adequate management. It is also known for its susceptibility to diseases such as leaf rust, scab and leaf spots, but resistant to powdery mildew, mosaic and Pyricularia oryzae Cav. This variety has an average cycle to Rio Grande do Sul. The silking occurs after 77 days and maturity at 128 days. The seeds were treated with the fungicide triadimenol (Baytan $®)$ at $2.0 \mathrm{~mL} \mathrm{~kg}^{-1}$ of seed and insecticide imidacloprid (Gaucho®) $1.0 \mathrm{~mL} \mathrm{~kg}^{-1}$ of seed.

Herbicides such as metsulfurommethyl (Ally®) at $6 \mathrm{~g} \mathrm{ha}^{-1}$ dose for dicotyledonous weeds and iodosulfurom methyl (Hussar®) at $100 \mathrm{~g} \mathrm{ha}^{-1}$ dose to poaceae weeds such as oats and ryegrass were used to control them in post-emergence stadium. During stalk elongation stadium, the control of insects in the shoot was applied insecticide imidacloprid + triflumuron (Connect $囚$ ) at $500 \mathrm{~mL} \mathrm{ha}^{-1}$ dose, in one application.

In foliar applications for disease prevention, fungicides such as Nativo, Opera and Priori Xtra were used at $0.6 \mathrm{~L} \mathrm{ha}^{-1}\left(600 \mathrm{~mL} \mathrm{ha}^{-1}\right)$ dose in two applications. These fungicides have as active principles strobilurin and triazole plus leaf adjuvant. While Tensor Plus®, a leaf adjuvant, was used as a control. The distribution of treatments is shown in Table 1.

A portable pressurized spray with $\mathrm{CO}_{2}$ and $100 \mathrm{~L} \mathrm{ha}^{-1}$ rate was used for application. The spray nozzles were simple flat jets, the Teejet XR110015 series, and the operating pressure was 2.0 bar, in order to release fine droplets. The speed moviment was $5.76 \mathrm{~km} \mathrm{~h}^{-1}\left(1.6 \mathrm{~ms}^{-1}\right)$. The preparation order of this broth was $1 \mathrm{~L}$ water + Tensor Plus + Nimbus Oil + Priori Xtra Fungicide + required volume of water to complete $2 \mathrm{~L}$ for the final broth. Also, the measurement of $\mathrm{pH}$ in the broth preparation was 
done in each treatment. The water used in this trial had $6.64 \mathrm{pH}$.
In Table 2 the weather conditions, at the beginning and end of applications with fungicides, are indicated.

Table 1. Distribution of treatments.

\begin{tabular}{lccc}
\hline & Treatment & & \multicolumn{2}{c}{ Broth preparation (mL / 2 L) } \\
\hline Fungicide & Adjuvant & Fungicide & Adjuvant \\
\hline 1. Nativo & - & $12 \mathrm{~mL}$ & - \\
2. Nativo & Áureo & $12 \mathrm{~mL}$ & $10 \mathrm{~mL}$ \\
3. Nativo & Break Thru & $12 \mathrm{~mL}$ & $2 \mathrm{~mL}$ \\
4. Nativo & LI 700 & $12 \mathrm{~mL}$ & $3 \mathrm{~mL}$ \\
5. Nativo & Glycerine & $12 \mathrm{~mL}$ & $20 \mathrm{~mL}$ \\
6. Opera & - & $12 \mathrm{~mL}$ & - \\
7. Opera & Assist & $12 \mathrm{~mL}$ & $10 \mathrm{~mL}$ \\
8. Opera & Break Thru & $12 \mathrm{~mL}$ & $2 \mathrm{~mL}$ \\
9. Opera & LI 700 & $12 \mathrm{~mL}$ & $3 \mathrm{~mL}$ \\
10. Opera & Glycerine & $12 \mathrm{~mL}$ & $20 \mathrm{~mL}$ \\
11. Priori Xtra & - & - & - \\
12. Priori Xtra & Nimbus & - & $10 \mathrm{~mL}$ \\
13. Priori Xtra + Tensor Plus & Nimbus & $3.0 \mathrm{~mL}$ & $3.0 \mathrm{~mL}$ \\
14. Priori Xtra + Tensor Plus & Nimbus & $5.0 \mathrm{~mL}$ & $3.0 \mathrm{~mL}$ \\
15. Control & - & - & - \\
\hline
\end{tabular}

Table 2. Information relating to fungicides application in wheat crop.

\begin{tabular}{lcccc}
\hline \multicolumn{1}{c}{ Aplications } & \multicolumn{2}{c}{ First sept, $15 \mathrm{th} / 2011$ ) } & \multicolumn{2}{c}{ Second (Oct., 05th/2011) } \\
\hline Timetable & Beginning & End & Beginning & End \\
Air temperature & $15 \mathrm{~h} 30 \mathrm{~min}$ & $16 \mathrm{~h} 40 \mathrm{~min}$ & $15 \mathrm{~h} 30 \mathrm{~min}$ & $16 \mathrm{~h} 10 \mathrm{~min}$ \\
Relative humidity & $20.5{ }^{\circ} \mathrm{C}$ & $23.0^{\circ} \mathrm{C}$ & $28.1{ }^{\circ} \mathrm{C}$ & $27.2^{\circ} \mathrm{C}$ \\
Wind speed & $57.5 \%$ & $48 \%$ & $50 \%$ & $48.5 \%$ \\
\hline
\end{tabular}

The harvest took place on November $20^{\text {th }}$, 2011, with a combine harvester plots, so that eight core rows were picked up for each plot, totaling a sample area of $13.6 \mathrm{~m}^{2}$. The harvested seeds were cleaned, weighed and water content was determined. They were immediately placed in multi-coated paper bags and stored in a dry environment $(50 \%$ relative humidity) at the Application Technology Laboratory from the University of Passo Fundo, at room temperature until the end of January 2012. Then, the samples were placed in four plastic bags and to control pests of stored seeds, a tablet of the insecticide steaming phosphine (Gastoxin ${ }^{\circledR}$ ) was placed in each bag. These bags were transferred to a dry chamber of the Seed Analysis Laboratory of the University of Passo Fundo, where they were kept under $20^{\circ} \mathrm{C}$. In May 2012, they were sent to Seeds and Plant Evaluation Laboratory (LASP), which remained under refrigeration until the seed analysis.
Analyses were carried out at LASP and Quality of Agricultural Products Control (LACON), both from Center of Exact Sciences and Technology of the Western Paraná State University (UNIOESTE), Campus Cascavel - PR - Brazil. The evaluations were only at the beginning of the experiment to check seeds quality, and the tests were:

a) Germination: there were two repetitions of 100 seeds for each sample, placed on filter paper substrate, in rolls, previously moistened with distilled water (2.5 times the mass of dry paper soaked in water), which were taken to the germinator temperature of $25{ }^{\circ} \mathrm{C}$. The seedlings count was carried out on the eighth day after sowing, and the results were expressed in percentage (BRASIL, 2009).

b) Cold test: two repetitions of 100 seeds were sown on filter paper, wrapped in plastic bags and kept at $10{ }^{\circ} \mathrm{C}$ for seven days. After, they were 
placed in a germinator at $25^{\circ} \mathrm{C}$ and seedlings were counted on the fourth day (BARROS et al., 1999).

c) Accelerated aging: four replications of each treatment were previously weighed $( \pm 42.5 \mathrm{~g})$ and distributed to form a layer of seeds on the surface of the metal screen gerbox. Thus, in order to keep relative humidity inside the box, $40 \mathrm{~mL}$ of water were added $(100 \% \mathrm{RH})$. Plastic boxes remained at $41{ }^{\circ} \mathrm{C}$ of aging chamber for 48 hours after the seeds have been submitted to germination test as they were evaluated four days after sowing, and the results expressed as a percentage (BRASIL, 2009).

d) Moisture content: four samples of $5 \mathrm{~g}$ from each treatment were weighed, placed in aluminum capsules and dried at $105^{\circ} \mathrm{C}$ for 24 hours. The seeds were weighed again after dried and then moisture content was calculated according to Brasil (2009).

e) Mass of 1000 seeds: two samples of 100 seeds were counted at random, weighed on a 0.001 $\mathrm{g}$ precision scale. The average was expressed in grams, and transformed into a mass of a thousand seeds. In order to obtain real weight of seed mass, this amount was adjusted according to the moisture content, defined as an adjusted mass based on the average moisture content (BRASIL, 2009).

f) Electrical Conductivity: four samples of 50 pure seeds were weighed, placed in vials with 75 $\mathrm{mL}$ of deionized water and kept in BOD chamber at $25^{\circ} \mathrm{C}$ for 24 hours. After soaking, the samples were stirred and electrical conductivity reading was obtained. This value was divided by the mass and the results expressed as mmhos $\mathrm{cm}^{-1} \mathrm{~g}^{-1}$ (VIEIRA, 1994).

g) Controlled deterioration: the water content of seed samples was adjusted to $15.5 \%$ for this test, then, the seeds were wrapped in aluminum foil, packed in plastic and kept in a water bath for 48 hours at $40{ }^{\circ} \mathrm{C}$. The seeds were submitted to germination test and evaluation occurred on the fourth day (MARCOS FILHO; NOVEMBRE; CHAMMA, 2001).

h) Emergency in sand: four replications of 50 seeds from each treatment were used and sown in plastic boxes with washed sand. After seedling emergence, the counting considered normal seedlings on the eighth day after sowing date. The results were expressed in percentage (NAKAGAWA, 1994).

i) Aflatoxins: the determination of $\mathrm{B} 1, \mathrm{~B} 2$, G1 and G2 was obtained by 991.31 AOAC official method (AOAC, 1982), with immunoaffinity columns, followed by HPLC injection. The aflatoxin calibration curves were prepared by injecting $0.5 \mathrm{mg}$ $\mathrm{L}^{-1}$ aliquots of aflatoxin standard solutions (B1, B2, $\mathrm{G} 1$ and $\mathrm{G} 2$ ) to get concentrations in the following orders: $0025 ; 12: 05,0075 ; 0.1$ and $0.125 \mathrm{mg} \mathrm{L}^{-1}$. The graphics of area versus mass of injected aflatoxins B1, B2, G1 and G2 were prepared to register the linearity of calibration curve, where $r^{2} \geq$ 0.99. The volume injected into HPLC was $20 \mu \mathrm{L}$ and the run time was 15 minutes per sample. The samples were obtained in duplicate and the average was calculated. The liquid chromatography was carried out under these conditions: temperature: 40 ${ }^{\circ} \mathrm{C}$; column of $4.6 \mathrm{~mm} \mathrm{x} 25 \mathrm{~cm}, 5 \mu \mathrm{m} \mathrm{C} 18$ (Kromasil); mobile phase - methanol:water (40:60), degassed isocratic and fluorescence detector - 365 $\mathrm{nm}$ excitation and $450 \mathrm{~nm}$ emission. The identification of toxins was carried out based on the retention time and quantitative analysis was obtained by the area of toxins. Elution of aflatoxin G2, G1, and B1 B2 occurred at 6.874, 7.813, 10.664 and 12.071 minutes, with quantitative limits of 0.5 , $0.5,0.05$ to $0.5 \mu . \mathrm{kg}^{-1}$ and recovery coefficients of $68,71,93$ and $98 \%$, respectively.

The experimental design was completely randomized, with results submitted to normality test and homogeneity of variances analyzed by the Shapiro-Wilk test, and the average comparison by Scott-Knott at 5\% probability, using Sisvar® software (FERREIRA, 2008).

No campo foram especificadas as repetições dos tratamentos, e cada teste de qualidade tem metodologia específica e foi descrita no respectivo item. Haveria necessidade de repetir aqui?

\section{RESULTS AND DISCUSSION}

Table 3 shows the germination percentage averages for normal, abnormal seedlings and dead seeds of wheat under initial condition and submitted to accelerated aging and cold test, treated with fungicide and adjuvant application during crop development.

There was a significant difference in treatments 1 (Nativo without adjuvant), 3 (Nativo + adjuvant Break Thru), 6 (Opera without adjuvant) and 7 (Opera + Assist adjuvant), with lower germination percentage than the others, except for treatment 1 which showed less than $80 \%$ of germination. The percentages of abnormal seedlings and dead seeds were not affected by the treatments, indicating that there was no influence of the tested products. 
Table 3. Germination percentage averages for normal, abnormal seedlings and dead seeds of wheat in initial condition and submitted to accelerated aging tests and emergency in sand after treatments with fungicides and adjuvants during crop development.

\begin{tabular}{cccccccccc}
\hline & \multicolumn{3}{c}{$\%$ germination } & \multicolumn{3}{c}{$\%$ abnormals } & \multicolumn{3}{c}{$\%$ dead seeds } \\
\cline { 2 - 8 } Treatment & initial & $\begin{array}{c}\text { cold } \\
\text { test }\end{array}$ & acc. aging. & initial & cold test & acc. aging. & initial & test & acc. aging. \\
\hline 1 & $79 \mathrm{a}$ & $90 \mathrm{a}$ & $70 \mathrm{a}$ & $7 \mathrm{a}$ & $3 \mathrm{a}$ & $2 \mathrm{a}$ & $14 \mathrm{a}$ & $7 \mathrm{a}$ & $28 \mathrm{~b}$ \\
2 & $89 \mathrm{~b}$ & $94 \mathrm{a}$ & $82 \mathrm{~b}$ & $4 \mathrm{a}$ & $1 \mathrm{a}$ & $5 \mathrm{c}$ & $8 \mathrm{a}$ & $6 \mathrm{a}$ & $13 \mathrm{a}$ \\
3 & $82 \mathrm{a}$ & $92 \mathrm{a}$ & $80 \mathrm{~b}$ & $6 \mathrm{a}$ & $1 \mathrm{a}$ & $5 \mathrm{c}$ & $8 \mathrm{a}$ & $7 \mathrm{a}$ & $15 \mathrm{a}$ \\
4 & $86 \mathrm{~b}$ & $94 \mathrm{a}$ & $84 \mathrm{~b}$ & $4 \mathrm{a}$ & $2 \mathrm{a}$ & $3 \mathrm{~b}$ & $10 \mathrm{a}$ & $4 \mathrm{a}$ & $13 \mathrm{a}$ \\
5 & $87 \mathrm{~b}$ & $91 \mathrm{a}$ & $71 \mathrm{~b}$ & $3 \mathrm{a}$ & $2 \mathrm{a}$ & $3 \mathrm{~b}$ & $10 \mathrm{a}$ & $7 \mathrm{a}$ & $26 \mathrm{~b}$ \\
6 & $85 \mathrm{a}$ & $90 \mathrm{a}$ & $68 \mathrm{a}$ & $5 \mathrm{a}$ & $3 \mathrm{a}$ & $9 \mathrm{c}$ & $9 \mathrm{a}$ & $8 \mathrm{a}$ & $23 \mathrm{~b}$ \\
7 & $85 \mathrm{a}$ & $90 \mathrm{a}$ & $60 \mathrm{a}$ & $3 \mathrm{a}$ & $4 \mathrm{a}$ & $8 \mathrm{c}$ & $12 \mathrm{a}$ & $7 \mathrm{a}$ & $32 \mathrm{~b}$ \\
8 & $87 \mathrm{~b}$ & $93 \mathrm{a}$ & $80 \mathrm{~b}$ & $2 \mathrm{a}$ & $2 \mathrm{a}$ & $4 \mathrm{~b}$ & $8 \mathrm{a}$ & $5 \mathrm{a}$ & $16 \mathrm{a}$ \\
9 & $91 \mathrm{~b}$ & $92 \mathrm{a}$ & $77 \mathrm{~b}$ & $2 \mathrm{a}$ & $2 \mathrm{a}$ & $8 \mathrm{c}$ & $8 \mathrm{a}$ & $5 \mathrm{a}$ & $15 \mathrm{a}$ \\
10 & $91 \mathrm{~b}$ & $94 \mathrm{a}$ & $55 \mathrm{a}$ & $3 \mathrm{a}$ & $1 \mathrm{a}$ & $4 \mathrm{~b}$ & $7 \mathrm{a}$ & $6 \mathrm{a}$ & $41 \mathrm{~b}$ \\
11 & $90 \mathrm{~b}$ & $93 \mathrm{a}$ & $72 \mathrm{~b}$ & $2 \mathrm{a}$ & $1 \mathrm{a}$ & $1 \mathrm{a}$ & $9 \mathrm{a}$ & $6 \mathrm{a}$ & $27 \mathrm{~b}$ \\
12 & $88 \mathrm{~b}$ & $96 \mathrm{a}$ & $53 \mathrm{a}$ & $1 \mathrm{a}$ & $1 \mathrm{a}$ & $5 \mathrm{c}$ & $10 \mathrm{a}$ & $4 \mathrm{a}$ & $42 \mathrm{~b}$ \\
13 & $90 \mathrm{~b}$ & $92 \mathrm{a}$ & $62 \mathrm{a}$ & $2 \mathrm{a}$ & $2 \mathrm{a}$ & $3 \mathrm{~b}$ & $9 \mathrm{a}$ & $6 \mathrm{a}$ & $35 \mathrm{~b}$ \\
14 & $88 \mathrm{~b}$ & $95 \mathrm{a}$ & $67 \mathrm{a}$ & $1 \mathrm{a}$ & $1 \mathrm{a}$ & $3 \mathrm{~b}$ & $10 \mathrm{a}$ & $4 \mathrm{a}$ & $30 \mathrm{~b}$ \\
Control & $89 \mathrm{~b}$ & $93 \mathrm{a}$ & $79 \mathrm{~b}$ & $1 \mathrm{a}$ & $2 \mathrm{a}$ & $5 \mathrm{a}$ & $8 \mathrm{a}$ & $5 \mathrm{a}$ & $19 \mathrm{a}$ \\
\hline
\end{tabular}

Averages followed by the same letter in column do not differ among themselves by Scott-Knott test at 5\% significance. The presented data came from the original observations followed by the letters in average comparison with transformation in $\sqrt{(x+0.5)}$. Treatments 1: Nativo $(12 \mathrm{~mL})$ without adjuvant; 2: Nativo $(12 \mathrm{~mL})+$ adjuvant Aureo $(10 \mathrm{~mL})$ with $0.5 \mathrm{~L}$ ha- ${ }^{1}$ dose, $3:$ Nativo $(12 \mathrm{~mL})+$ adjuvant Break Thru $(2 \mathrm{~mL})$ with $0.10 \mathrm{~L} \mathrm{ha}^{-1}$; 4: Nativo $(12 \mathrm{~mL})+$ adjuvant LI $700(3 \mathrm{~mL})$ with $0.15 \mathrm{~L} \mathrm{ha}^{-1}$ dose; 5: Nativo $(12 \mathrm{~mL})+$ adjuvante Glycerine $(20 \mathrm{~mL})$ with $1.0 \mathrm{~L} \mathrm{ha}^{-1}$ dose; 6 : Opera $(12 \mathrm{~mL})$ without adjuvant; 7: Opera $(12 \mathrm{~mL})+$ adjuvant Assist $(10 \mathrm{~mL}) \mathrm{with}_{0.5 \mathrm{~L} \mathrm{ha}}{ }^{-1}$ dose; 8: Opera $(12 \mathrm{~mL})+$ adjuvant Break Thru $(2 \mathrm{~mL})$ with $0.10 \mathrm{~L} \mathrm{ha}^{-1}$ dose; 9: Opera $(12 \mathrm{~mL})+$ adjuvant LI $700(3 \mathrm{~mL}) 0.15 \mathrm{~L} \mathrm{ha}{ }^{-1}$ dose; 10: Opera $(12 \mathrm{~mL})+$ adjuvant Glycerine $(20 \mathrm{~mL})$ with $1.0 \mathrm{~L} \mathrm{ha}^{-1}$ dose; 11 : Priori Xtra without adjuvant; 12: Priori Xtra + adjuvant Nimbus $(10 \mathrm{~mL})$ with $0.5 \%$ dose; 13 : Priori Xtra $(3 \mathrm{~mL})+$ adjuvant Nimbus $(3 \mathrm{~mL})$ with $0.15 \%$ dose; 14 : Priori Xtra $(3 \mathrm{~mL})+$ adjuvant Nimbus ( $3 \mathrm{~mL}$ ) with $0.25+0.15 \%$ dose. Acc. aging corresponds to the accelerate aging test results.

Garcia Júnior, Vechiato and Menten (2008) found out no significant difference in wheat seed germination BR 18 Terena variety with the use of fungicides as tebuconazole, captan, difeconazole, tolyfluanida, fludioxonil, triflumizole, triadimenol, triticonazole, thiabendazole and thiophanate methyl.

Rampim et al. (2012) studied the physiological quality of seeds of three wheat varities submitted to treatments with bio-stimulant, triadimenol and Azospirillum brasilense, and observed that there was no influence on germination with the interaction among the treatments and varieties used.

These results are different from the ones obtained by Marini et al. (2011), who studied the physiological quality of CD 111 and CD 108 wheat varieties from COODETEC, and observed decrease in germination rate in relation to increased
Carboxim Tiram fungicide doses, including the recommended $270 \mathrm{mg} \mathrm{L}^{-1}$ dose.

Asghar et al (2016) concluded that seedborne diseases have been found to affect the growth and productivity of crop plants as the liable pathogens attack and destroy the seedlings. Fusarium and Alternaria spp. are also responsible for reducing the germination rate and inducing seedling blight. The seed germination rate was lower in contaminated wheat in comparison to healthy wheat samples. For instance, the seed germination rates in healthy and contaminated wheat samples were $84.6 \%$ and $45.2 \%$, respectively. On the basis of obtained results, it was also concluded that fungal pathogens have adverse effects on the germination of wheat seeds.

In the cold test, the results showed no significant difference, indicating that wheat is resistant to low temperatures, and the results were 
consistent with the germination test. In seeds evaluated after accelerated aging, it was observed that the stress caused by heat affected germination significantly. The treatments 2 (Nativo + adjuvant Aureo) and 4 (Native + adjuvant LI 700) presented over $80 \%$ of germination, which was considered adequate for trading as seeds. Such results are in accordance with Instruction No. 25 of December, $16^{\text {th }}, 2005$, which establishes $80 \%$ as minimum germination answer for the production of first and second wheat seed generations (MAPA, 2009). The other treatments, although with statistical difference, did not show good germination percentage.

Gagliardi et al. (2009) analyzed the residual effect of fungicides applied in soybean seeds by tests of germination, accelerated aging, emergency in sand and sanity. They concluded that the followed treatments Priori + Nimbus, Aproach + Nimbus, Priori Xtra + Nimbus, Sphere + Aureo, Opera, Stratego + Aureo, Nativo + Aureo, Impact Duo + Oppa, Celeiro + Iharol, Battle + Oppa, Aproach Prima + Nimbus and Folicur did not influence the seeds quality. However, Rufino et al. (2013) observed that the germination percentage is positively affected by treatment with fungicide when applied alone or with $\mathrm{Zn}$ and polymer combined application.

It is indicated that in accelerated aging and electrical conductivity tests, the initial water content in the studied samples should be close to one another during physiological quality evaluation, consequently, this would avoid interference in the results (VIEIRA, 1994; HAMPTON; TEKRONY, 1995).

Table 4. Averages of moisture content, mass of a thousand seeds and the mass of a thousand seeds adjusted according to average of seeds moisture content (7.39\%) after treatments with fungicides and adjuvants during crop development.

\begin{tabular}{cccc}
\hline Treatments & $\begin{array}{c}\text { Moisture content } \\
(\%)\end{array}$ & $\begin{array}{c}\text { Mass of thousand } \\
\text { seeds }(\mathrm{g})\end{array}$ & $\begin{array}{c}\text { Mass of thousand seeds (g) adjusted } \\
\text { to moisture content }\end{array}$ \\
\hline 1 & $7.3 \mathrm{a}$ & $40.52 \mathrm{~b}$ & $41.32 \mathrm{a} \mathrm{b} \mathrm{c}$ \\
2 & $6.9 \mathrm{a}$ & $43.19 \mathrm{~b}$ & $46.53 \mathrm{a} \mathrm{b} \mathrm{d}$ \\
3 & $6.7 \mathrm{a}$ & $41.21 \mathrm{~b}$ & $45.80 \mathrm{a} \mathrm{b} \mathrm{d}$ \\
4 & $7.1 \mathrm{a}$ & $40.64 \mathrm{~b}$ & $43.15 \mathrm{a} \mathrm{b} \mathrm{c}$ \\
5 & $6.5 \mathrm{a}$ & $40.94 \mathrm{~b}$ & $46.49 \mathrm{a} \mathrm{b} \mathrm{d}$ \\
6 & $6.8 \mathrm{a}$ & $42.23 \mathrm{c}$ & $46.07 \mathrm{a} \mathrm{b} \mathrm{d}$ \\
7 & $7.3 \mathrm{a}$ & $42.02 \mathrm{c}$ & $42.79 \mathrm{a} \mathrm{b} \mathrm{c}$ \\
8 & $6.1 \mathrm{a}$ & $42.63 \mathrm{c}$ & $52.30 \mathrm{~d}$ \\
9 & $6.6 \mathrm{a}$ & $42.38 \mathrm{c}$ & $47.23 \mathrm{~b} \mathrm{~d}$ \\
10 & $8.0 \mathrm{a}$ & $42.42 \mathrm{c}$ & $43.16 \mathrm{a} \mathrm{b} \mathrm{c}$ \\
11 & $8.4 \mathrm{~b}$ & $41.75 \mathrm{c}$ & $36.55 \mathrm{c}$ \\
12 & $8.4 \mathrm{~b}$ & $42.87 \mathrm{c}$ & $37.55 \mathrm{c}$ \\
13 & $7.9 \mathrm{~b}$ & $42.98 \mathrm{c}$ & $40.14 \mathrm{a} \mathrm{b} \mathrm{c}$ \\
14 & $8.1 \mathrm{~b}$ & $43.19 \mathrm{c}$ & $39.23 \mathrm{a} \mathrm{c}$ \\
Control & $8.6 \mathrm{~b}$ & $33.83 \mathrm{a}$ & $28.84 \mathrm{e}$ \\
\hline
\end{tabular}

Averages followed by the same letter in column do not differ among themselves by Scott-Knott test at $5 \%$ significance. The presented data came from the original observations followed by the letters in average comparison with transformation in $\sqrt{(x+0.5)}$. Treatments 1: Nativo $(12 \mathrm{~mL})$ without adjuvant; 2: Nativo $(12 \mathrm{~mL})+$ adjuvant Aureo $(10 \mathrm{~mL})$ with $0.5 \mathrm{~L} \mathrm{ha}^{-1}$ dose, 3: Nativo $(12 \mathrm{~mL})+$ adjuvant Break Thru $(2 \mathrm{~mL})$ with $0.10 \mathrm{~L} \mathrm{ha}^{-1}$; 4: Nativo $(12 \mathrm{~mL})+$ adjuvant LI $700(3 \mathrm{~mL})$ with $0.15 \mathrm{~L} \mathrm{ha}^{-1}$ dose; 5: Nativo $(12 \mathrm{~mL})+$ adjuvante Glycerine $(20 \mathrm{~mL})$ with $1.0 \mathrm{~L} \mathrm{ha}^{-1}$ dose; 6: Opera $(12 \mathrm{~mL})$ without adjuvant; 7: Opera $(12 \mathrm{~mL})+$ adjuvant Assist $(10 \mathrm{~mL})$ with $0.5 \mathrm{~L} \mathrm{ha}^{-1}$ dose; 8: Opera $(12 \mathrm{~mL})+$ adjuvant Break Thru $(2 \mathrm{~mL})$ with $0.10 \mathrm{~L} \mathrm{ha}^{-1}$ dose; 9: Opera $(12 \mathrm{~mL})+$ adjuvant LI $700(3 \mathrm{~mL}) 0.15 \mathrm{~L} \mathrm{ha}^{-1}$ dose; 10: Opera $(12 \mathrm{~mL})+$ adjuvant Glycerine $(20 \mathrm{~mL})$ with $1.0 \mathrm{~L} \mathrm{ha}^{-1}$ dose; 11: Priori Xtra without adjuvant; 12: Priori Xtra + adjuvant Nimbus $(10 \mathrm{~mL})$ with $0.5 \%$ dose; 13 : Priori Xtra $(3 \mathrm{~mL})+$ adjuvant Nimbus $(3 \mathrm{~mL})$ with $0.15 \%$ dose; 14 : Priori Xtra $(3 \mathrm{~mL})+$ adjuvant Nimbus ( $3 \mathrm{~mL})$ with $0.25+0.15 \%$ dose.

According to Boligon et al. (2011), there are numerous existing tests that can be used to evaluate the seeds physiological quality, however, there are few studies that relate these tests with seedlings emergence in the field. The accelerated aging test shows the closest result to seedlings emergence in the field.

The averages of moisture content, mass of a thousand seeds and the mass of a thousand seeds adjusted according to average of seeds moisture 
content $(7.39 \%)$ are shown in Table 4 . The moisture content of wheat seeds showed a significant difference in the treatments 1 to 10 , differing from the others and the control that showed higher moisture contents.

Concerning the mass of a thousand seeds, a significant difference from the control in relation to other treatments. On the other hand, treatments 1 (Nativo without adjuvant), 3 (Nativo + adjuvant Break Thru), 4 (Nativo + LI 700 adjuvant) 5 (Nativo + Glycerine adjuvant) and 11 (Priori Xtra without adjuvant) differ from the others, with less mass. It can be observed that the treatments 2 (Nativo + adjuvant Aureo) and 14 (Priori Xtra + adjuvant Nimbus with 0:25 + 0:15\% dose) showed the highest seed mass, and different adjusted mass values, which means that the increasing moisture was responsible for the mass increase in treatment 14.

Barbieri et al. (2013) found out that smaller size or smaller seed mass may have lower physiological quality. However, Avila et al. (2005) studied canola seed, and observed no relationship between mass of a thousand seeds and vigor. This same behavior was observed for maize seeds in studies carried out by Andrade et al. (1997).

Toledo and Marcos Filho (1977) stated that there is influence of moisture content in the mass of a thousand seeds and hectolitre weight of wheat. They also recommended that researchers should be aware when comparing results in samples with different moisture content values.

The averages of electrical conductivity, controlled deterioration and emergence in sand are shown in Table 5.

Table 5. Averages of electrical conductivity, controlled deterioration and emergence in sand of wheat seeds after treatments with fungicides during the crop development.

\begin{tabular}{cccc}
\hline Treatments & EC $\left(\mu S / \mathrm{cm}^{-1} / \mathrm{g}^{-1}\right)$ & Deterioration $(\%)$ & Emergence $(\%)$ \\
\hline 1 & $21.79 \mathrm{~b}$ & $83 \mathrm{a}$ & $73 \mathrm{a}$ \\
2 & $17.74 \mathrm{a}$ & $84 \mathrm{a}$ & $92 \mathrm{a}$ \\
3 & $18.84 \mathrm{~b}$ & $89 \mathrm{a}$ & $88 \mathrm{a}$ \\
4 & $17.15 \mathrm{a}$ & $80 \mathrm{a}$ & $95 \mathrm{a}$ \\
5 & $17.71 \mathrm{a}$ & $91 \mathrm{a}$ & $89 \mathrm{a}$ \\
6 & $19.98 \mathrm{~b}$ & $85 \mathrm{a}$ & $91 \mathrm{a}$ \\
7 & $14.67 \mathrm{a}$ & $85 \mathrm{a}$ & $93 \mathrm{a}$ \\
8 & $17.53 \mathrm{a}$ & $77 \mathrm{a}$ & $92 \mathrm{a}$ \\
9 & $17.53 \mathrm{a}$ & $90 \mathrm{a}$ & $90 \mathrm{a}$ \\
10 & $18.00 \mathrm{a}$ & $84 \mathrm{a}$ & $92 \mathrm{a}$ \\
11 & $23.95 \mathrm{~b}$ & $83 \mathrm{a}$ & $85 \mathrm{a}$ \\
12 & $22.86 \mathrm{~b}$ & $88 \mathrm{a}$ & $96 \mathrm{a}$ \\
13 & $25.18 \mathrm{~b}$ & $89 \mathrm{a}$ & $93 \mathrm{a}$ \\
14 & $21.41 \mathrm{~b}$ & $89 \mathrm{a}$ & $89 \mathrm{a}$ \\
Control & $19.75 \mathrm{~b}$ & $88 \mathrm{a}$ & $89 \mathrm{a}$ \\
\hline
\end{tabular}

Averages followed by the same letter in column do not differ among themselves by Scott-Knott test at 5\% significance. The presented data came from the original observations followed by the letters in average comparison with transformation in $\sqrt{(x+0.5)}$. Treatments 1: Nativo $(12 \mathrm{~mL})$ without adjuvant; 2: Nativo $(12 \mathrm{~mL})+$ adjuvant Aureo $(10 \mathrm{~mL})$ with $0.5 \mathrm{~L}$ ha- ${ }^{1}$ dose, $3:$ Nativo $(12 \mathrm{~mL})+$ adjuvant Break Thru $(2 \mathrm{~mL})$ with $0.10 \mathrm{~L} \mathrm{ha}^{-1}$; 4: Nativo $(12 \mathrm{~mL})+$ adjuvant LI $700(3 \mathrm{~mL})$ with $0.15 \mathrm{~L} \mathrm{ha}^{-1}$ dose; 5: Nativo $(12 \mathrm{~mL})+$ adjuvante Glycerine $(20 \mathrm{~mL})$ with $1.0 \mathrm{~L} \mathrm{ha}^{-1}$ dose; 6 : Opera $(12 \mathrm{~mL})$ without adjuvant; 7: Opera $(12 \mathrm{~mL})+$ adjuvant Assist $(10 \mathrm{~mL})$ with $0.5 \mathrm{~L} \mathrm{ha}{ }^{-1}$ dose; 8: Opera $(12 \mathrm{~mL})+$ adjuvant Break Thru $(2 \mathrm{~mL})$ with $0.10 \mathrm{~L} \mathrm{ha}^{-1}$ dose; 9: Opera $(12 \mathrm{~mL})+\operatorname{adjuvant} \mathrm{LI} 700(3 \mathrm{~mL}) 0.15 \mathrm{~L} \mathrm{ha}{ }^{-1}$ dose; 10: Opera $(12 \mathrm{~mL})+$ adjuvant Glycerine $(20 \mathrm{~mL})$ with $1.0 \mathrm{~L} \mathrm{ha}^{-1}$ dose; 11: Priori Xtra without adjuvant; 12: Priori Xtra + adjuvant Nimbus $(10 \mathrm{~mL})$ with $0.5 \%$ dose; 13 : Priori Xtra $(3 \mathrm{~mL})+$ adjuvant Nimbus $(3 \mathrm{~mL})$ with $0.15 \%$ dose; 14 : Priori Xtra $(3 \mathrm{~mL})+$ adjuvant Nimbus $(3 \mathrm{~mL})$ with $0.25+0.15 \%$ dose. Acc. aging corresponds to the accelerate aging test results.

EC corresponds to results of electrical conductivity test.

Treatments 1 (Nativo without adjuvant), 3 (Nativo + adjuvant Break Thru), 6 (Opera without adjuvant), 11 (Priori Xtra without adjuvant), 12 (Priori Xtra + adjuvant Nimbus), 13 (Priori Xtra (3 $\mathrm{mL})$ Nimbus + adjuvant $(3 \mathrm{~mL}))$ and 14 (Priori Xtra
+ Nimbus adjuvant at $0.25+0.15 \%$ dose) and the control showed the highest values, indicating greater deterioration to seeds membranes. This results corresponds to the lowest seed vigor in treatments, which differed significantly from the others. 
Marini et al. (2011) registered that electrical conductivity answer increased significantly as the concentration of Thiram Carboxim fungicide increased in the studied genotypes. This suggests that the product caused damage to membranes integrity, thus, there was no total system rearrangement.

The electrical conductivity test aimed at evaluating the amount of ions present in soaking water and, indirectly, the seed vigor, based on the fact that the vigor is related to integrity of cell membrane system (MARCOS FILHO; CICERO; SILVA, 1987).

According to seed germination after controlled deterioration test, the results showed no significant difference among treatments, including the control. Only treatment 8 (Opera + Break Thru adjuvant) was an exception, whose germination was superior to $80 \%$. Although the electrical conductivity and accelerated aging tests have indicated possible change in the physiological quality, controlled deterioration test showed vigorous seeds.

In soybean seeds, Marcos Filho, Novembre e Chamma (2001) found out that the results for the controlled deterioration test were similar to those ones that were obtained after accelerated aging. Both tests were consistent in evaluating physiological seed quality, consequently they differed with the present results, which showed germination superior to $80 \%$ only in two treatments, after the seeds were submitted to accelerated aging test. Santorum et al (2013) also observed that the accelerated aging and controlled deterioration tests showed similar results in soybean seeds, so they are indicated to distinguish the vigor among the lots.

Seedlings emergency in sand showed no significant difference among treatments, and, except for the treatment 1 (Nativo without adjuvant), all of them showed emergence superior to $80 \%$. These results are similar to Garcia Junior, Vechiato and Menten (2008), which obtained no significant differences for emergence among treatments with fungicides and control in wheat seeds. This indicated an absence of negative or positive effects, without influence of products tested on seed germination.

The results for the detection analysis of aflatoxins in wheat seeds treated with fungicides during their development are shown in Table 6.

Table 6. Levels of aflatoxin (B1, B2, G1 and G2) in wheat seeds after fungicide and adjuvant treatments during crop development.

\begin{tabular}{|c|c|c|c|c|}
\hline \multirow[b]{2}{*}{ Conditions } & \multicolumn{2}{|c|}{ Sample } & \multirow[b]{2}{*}{ Average } & \multirow[b]{2}{*}{ Total } \\
\hline & 1 & 2 & & \\
\hline 1 & nd & $\mathrm{Nd}$ & nd & $\mathrm{Nd}$ \\
\hline 2 & nd & $\mathrm{Nd}$ & nd & $\mathrm{Nd}$ \\
\hline 3 & nd & $\mathrm{Nd}$ & nd & $\mathrm{Nd}$ \\
\hline 4 & nd & nd & nd & $\mathrm{Nd}$ \\
\hline 5 & nd & nd & nd & $\mathrm{Nd}$ \\
\hline 6 & nd & nd & nd & $\mathrm{Nd}$ \\
\hline 7 & nd & nd & nd & $\mathrm{Nd}$ \\
\hline 8 & nd & nd & nd & $\mathrm{Nd}$ \\
\hline 9 & nd & nd & nd & $\mathrm{Nd}$ \\
\hline 10 & nd & nd & nd & $\mathrm{Nd}$ \\
\hline 11 & nd & nd & nd & $\mathrm{Nd}$ \\
\hline 12 & nd & nd & nd & $\mathrm{Nd}$ \\
\hline 13 & nd & nd & nd & $\mathrm{Nd}$ \\
\hline 14 & nd & nd & nd & $\mathrm{Nd}$ \\
\hline Control & nd & nd & nd & $\mathrm{Nd}$ \\
\hline
\end{tabular}

Notes: $\quad \mathrm{nd}=$ no detected; Recovering rates: $\mathrm{B} 1=68 \% ; \mathrm{B} 2=93 \% ; \mathrm{G} 1=71 \%$ e G2 $=68 \%$; Detection limits: $\mathrm{B} 1=0.5 \mu \mathrm{g} \mathrm{kg}^{-1} ; \mathrm{B} 2=0.05$ $\mu \mathrm{g} \mathrm{kg}^{-1} ; \mathrm{G} 1=0.5 \mu \mathrm{g} \mathrm{kg}^{-1}$ e G2$=0.5 \mu \mathrm{g} \mathrm{kg}^{-1}$

There was no presence of aflatoxins B1, B2, G1 and G2 in studied wheat seeds. This indicates that the presence of chemical contaminants in grains and the storage period after harvesting did not favor the occurrence of aflatoxins B1, B2, G1, and G2 in wheat seeds. Probably because these treatments during crop development were adequate and controlled the presence of fungi.

Taheri et al (2012) observed $3.1 \%$ and $7.4 \%$ contents of aflatoxin B1 in wheat flour, classified as 
superior to the established limits. The samples collected in the summer and winter respectively, according to the authors, may have interfered in moisture content during storage. Trombete et al (2014) also evaluated wheat grain and trading flour, although it has been detected the aflatoxin presence, the samples did not register with limits superior the ones established by Brazilian legislation $\left(5 \mu \mathrm{g} \mathrm{kg}^{-1}\right)$, thus they are safe as foodstuff.

\section{CONCLUSIONS}

The physiological quality of wheat seed is not affected when it fungicide is applied during crop development, with high germination rate, even under stress conditions such as cold and controlled deterioration.

The applied products guarantee sanitary quality for seeds in relation to aflatoxin presence even during storage period.

RESUMO: O trigo (Triticum aestivum L.) é um cereal com grande importância econômica e capacidade produtiva. Porém, é sujeito ao ataque de várias doenças o que demanda o uso de fungicidas durante o ciclo. Assim, este estudo teve como objetivo verificar a qualidade fisiológica e presença de aflatoxina em sementes de trigo quando tratadas com concentrações de fungicidas durante o desenvolvimento da cultura. Plantas da cultivar Mirante foram cultivadas com aplicação foliar de fungicidas com princípios ativos estrobilurina e triazol, adicionando-se adjuvante foliar. Após a colheita, avaliou-se o grau de umidade das sementes, porcentagem de germinação, envelhecimento acelerado, deterioração controlada, teste de frio, emergência em areia, condutividade elétrica e presença de aflatoxinas. Os resultados mostraram que a qualidade fisiológica e sanitária das sementes de trigo não foi influenciada pelo uso dos fungicidas testados. As sementes apresentaram elevado índice de germinação e emergência de plântulas, mesmo quando submetidas a condições de estresse.

PALAVRAS-CHAVE: Aplicação foliar. Germinação. Triticum aestivum L. Vigor.

\section{REFERENCES}

ANDRADE, R. V.; ANDREOLI, C.; BORBA, C. S.; AZEVEDO, J. T.; NETTO, D. A. M.; OLIVEIRA, A. C. Efeito da forma e do tamanho da semente no desempenho do campo de dois genótipos de milho. Revista Brasileira de Sementes, Londrina, v. 19, n. 1, p. 62-65, 1997. https://doi.org/10.17801/01013122/rbs.v19n1p62-65

AOAC - Association Official Analytical Chemists. 1982. Official methods of analysis of the Association Official Analytical Chemists. 12ed. AOAC, Washington, DC, USA.

ASGHAR, M.A.; AHMED, A.; IQBAL, J.; ZAHIR, E.; HINA NAUMAN, H. Fungal flora and aflatoxin contamination in Pakistani wheat kernels (Triticum aestivum L.) and their attribution in seed germination. Journal of Food and Drug Analysis, v. 24, p. 635-643, 2016. https://doi.org/10.1016/j.jfda.2016.02.001

ASTOLFI, P.; SANTOS, J.; SCHNEIDER, L.; GOMES, L. B.; SILVA, C. N.; TESSMANN, D. J.; DEL PONTE, E. M. 2011. Molecular survey of trichothecene genotypes of Fusarium graminearum species complex from barley in Southern Brazil. International of Food Microbiology, Turim, v. 148, n. 3, p. 197-201, 2011.

ÁVILA, M. R.; LUCCA E BRACCINI, A.; SCAPIM, C. A.; MARTORELLI, D. T.; ALBRECHT, L. P. 2005. Testes de laboratório em sementes de canola e a correlação com a emergência das plântulas em campo. Revista Brasileira de Sementes, Londrina, v. 27, n. 1, p. 62-70, 2005. https://doi.org/10.1590/S010131222005000100008

AYDIN, A.; GUNSEN, U.; DEMIREL, S. Total aflatoxin, aflatoxin B1 and ochratoxin A levels in Turkish wheat flour. Journal of Food and Drug Analysis, Taipei, v. 16, n. 2, p. 48-53, 2008. 
BARBIERI, A,P,P.; MARTIN, T. N. M.; MERTZ, L. M.; NUNES, U. R.; CONCEIÇÃO, G. M. Redução populacional de trigo no rendimento na qualidade fisiológica das sementes. Revista Ciência Agronômica, Fortaleza, v. 44, n. 4, p. 724-731, 2013. https://doi.org/10.1590/S1806-66902013000400008

BARROS, A. S.; DIAS, M. C. L. L.; CÍCERO, S. M.; KRZYZANOWSKI, F. C. Cold test. Teste de frio. In: KRZYZANOWSKI, F. C.; VIEIRA, R. D.; FRANÇA NETO, J. B. (Eds.) Vigor de sementes: conceitos e testes. Associação Brasileira de Tecnologia de Sementes. Londrina: ABRATES, Cap. 5, p. 1-15, 1999.

BASÍLICO, J.C. Micotoxinas en alimentos: el riesgo sobre la mesa. PhD Thesis. Centro de Publicaciones, Universidad Nacional del Litoral, Santa Fe. Argentina. 1995.

BOLIGON, A. A.; DAL'COL LÚCIO, A.; LOPES, S. J.; CARGNELUTTI FILHO, A.; GARCIA, D. C. 2011. Wheat seedling emergence estimated from seed analysis. Scientia Agricola, Piracicaba, v. 68, n. 3, p. 336341, 2011. https://doi.org/10.1590/S0103-90162011000300010

BRASIL. Ministério da Agricultura, Pecuária e Abastecimento. Regras para análise de sementes / Ministério da Agricultura, Pecuária e Abastecimento. Secretaria de Defesa Agropecuária. - Brasília: Mapa/ACS, 2009. $399 \mathrm{p}$.

BRASIL. Ministério da Saúde. Resolução RDC n. 7, de 18 de fevereiro de 2011. Dispõe sobre limites máximos tolerados (LMT) para micotoxinas em alimentos. Disponível em: http://www.brasilsus.com.br/legislacoes/rdc/107502-7.html 21/11/2012. Acesso em 24 mai. 2016.

COTTY P, JAIME-GARCIA R. Influences of climate on aflatoxin producing fungi and aflatoxin contamination. International Journal of Food and Microbiology.v.119, n.1-2, p.109-115, 2007. https://doi.org/10.1016/j.ijfoodmicro.2007.07.060

EMBRAPA - Empresa Brasileira de Pesquisa Agropecuária. Indicações técnicas para minimizar a contaminação de trigo por micotoxinas. Editora Embrapa Trigo. Disponível em:

$<$ www.embrapa.br/en/web/mobile/publicacoes/-/publicacao/1019435/indicacoes-tecnicas-para-minimizar-acontaminacao-de-trigo-por-micotoxinas >. Acesso em 29 dez. 2013.

EMBRAPA - Empresa Brasileira de Pesquisa Agropecuária. Sistema brasileiro de classificação de solos. Editora Embrapa Solos, 2013, 20 p. Disponível em: < www. http://livraria.sct.embrapa.br/liv_resumos/pdf/00053080.pdf >. Acesso em 3 jul. 2018.

FERREIRA, D. F. SISVAR: Um programa de análise e educação estatística. Revista Científica Symposium, Lavras, v. 6, n. 2, p. 36-41. 2008.

GAGLIARDI, B.; CARVALHO, T. C.; PUPIM, T. L.; GOMES JR., F. G.; TIMÓTEO, T. S.; KOBORI, N. N.; MORAES, M. H. D.; MENTEN, J. O. M. Efeito de fungicidas para controle da ferrugem asiática na qualidade de sementes de soja. Revista Brasileira de Sementes, Londrina, v. 31, n. 4, p. 120-125. 2009.

https://doi.org/10.1590/S0101-31222009000400014

GARCIA JÚNIOR, D.; VECHIATO, M. H.; MENTEN, J. O. M. Effects of fungicides on Fusarium graminearum control, germination, emergency and e height of seedlings in wheat seeds. Summa Phytopathologica, Botucatu, v. 34, n. 3, p. 280-283. 2008.

GHALI, R.; HMAISSIA-KHLIFA, K.; GHORBEL, H.; MAAROUFI, K.; HEDILI, A. Incidence of aflatoxins, ochratoxin a and zearalenone in tunisian foods. Food Control, Reading, v. 19, n. 9, p. 921-24, 2008. https://doi.org/10.1016/j.foodcont.2007.09.003

HAMPTON, J. G.; TEKRONY, D. M. Handbook of vigour test methods. Zurich: ISTA. 1995. 117p. 
INTERNATIONAL AGENCY FOR RESEARCH ON CANCER (IARC). Evaluation of carcinogenic risks to humans. IARC monographs, World Health Organization, v. 56, 599p. Lyon, 1993.

JACOBSEN, B. J. 14 good agricultural and harvest practices to reduce mycotoxin contamination in wheat in temperate countries. In: LESLIE, J.F.; LOGRIECO, A. Mycotoxin reduction in grain chains. Wiley Blackwell. 2014, p. 209.

JOUBRANE, K.; KHOURY, A. E. L.; LTEIF, R.; RIZK, T.; KALLASSY, M.; HILAN, C.; MAROUN, R. Occurrence of aflatoxin B1 and ochratoxin A in Lebanese cultivated wheat. Mycotoxin Research, v. 27, n. 4, p. 249-57, 2011. https://doi.org/10.1007/s12550-011-0101-z

MARCOS FILHO, J.; CICERO, S. M.; SILVA, W. R. Avaliação da qualidade de sementes. Editora FEALQ, Piracicaba, SP, 1987.

MARCOS FILHO, J.; NOVEMBRE, A. D. C.; CHAMMA, H. M. C. P. Teste de envelhecimento acelerado e de deterioração controlada para avaliação do vigor de sementes de soja. Scientia Agrícola, Piracicaba, v. 58, n. 2, p. 421-426, 2001. https://doi.org/10.1590/S0103-90162001000200029

MARINI, N.; TUNES, L. M.; SILVA, J. I.; MORAES, D. M.; OLIVO, F.; CANTOS, A. A. Carboxim Tiram fungicide effect in wheat seeds physiological quality (Triticum aestivum L.). Revista Brasileira de Ciências Agrárias, Recife, v. 6, n. 1, p. 17-22. 2011. https://doi.org/10.5039/agraria.v6i1a737

MENTEN, J. O. M.; MORAES, M. H. D. Avanço no tratamento e revestimento de sementes. Informativo Abrates, v. 20, n. p. 52-53, 2010.

MIELEZRSKI, F.; SCHUCH, L. O. B.; PESKE, S. T.; PANOZZO, L. E.; CARVALHO, R. R.; ZUCHI, J. Desempenho em campo de plantas isoladas de arroz híbrido em função da qualidade fisiológica das sementes. Revista Brasileira de Sementes, Londrina, v. 30, n. 3, p. 139-144, 2008. https://doi.org/10.1590/S010131222008000300018

MAPA - Ministério da Agricultura, Pecuária e Abastecimento. Instrução Normativa $\mathrm{N}^{\circ} 25$, de 16 de dezembro de 2005. Anexo XII - Padrões para produção e comercialização de sementes de trigo e de trigo duro. Disponível em:<http://extranet.agricultura.gov.br/sislegis-consulta/servlet/VisualizarAnexo?id=10813>. Acesso em 28 jan 28, 2009.

NAKAGAWA, J. Testes de vigor baseados na avaliação das plântulas. p. 49-85. In: VIEIRA, R. D.; CARVALHO, N. M. Testes de vigor em sementes. FUNEP, Jaboticabal, SP, Brazil, 1994.

NEME, K.; MOHAMMED, A. Mycotoxin occurrence in grains and the role of postharvest management as a mitigation strategies. A review. Food Control, v. 78. p. 412-425, 2017.

https://doi.org/10.1016/j.foodcont.2017.03.012

OBRAIN, G.R.; GEORGIANNA, D.R.; WILKINSON, J.R.; YU, J.; ABBAS, H.K.; BHATNAGAR, D.; CLEVELAND, T.E.; NIERMAN, W.; PAYNE, G.A. The effect of elevated temperature on gene transcription and aflatoxin biosynthesis. Mycologia. v. 99, n. 2, p. 232-239, 2007.

https://doi.org/10.1080/15572536.2007.11832583

https://doi.org/10.3852/mycologia.99.2.232

PESKE, S. T.; LUCCA FILHO, O. A.; BARROS, A. C. S. A. Produção de Sementes. In: Sementes: fundamentos científicos e tecnológicos. Ed. Universitária, p. 12-93, UFPel, Pelotas, 2006.

RAMPIM, L.; RODRIGUES-COSTA, A. C. P.; NACKE, H.; KLEIN, J.; GUIMARÃES, V. F. Qualidade fisiológica de sementes de três cultivares de trigo submetidas à inoculação e diferentes tratamentos. Revista Brasileira de Sementes, Londrina, v. 34, n. 4, p. 678-685, 2012. https://doi.org/10.1590/S010131222012000400020 
RAZDARI, H.B.; NOSRATI, A.C.; GHAEMI, N.; ARA, S. M. An assessment of aflatoxin levels in wheat samples of 5 top provinces of Iran. Bulletin of Environment, Pharmacology and Life Sciences. v.3, n. especial, p. 237-242. 2014.

RUFINO, C. A.; TAVARES, L. C.; BRUNES, A. P.; LEMES, E. S.; VILLELA, F. A. Treatment of wheat seed with zinc, fungicide, and polymer: seed quality and yield. Journal of Seed Science, Londrina, v. 35, n. 1, p. 106-112, 2013. https://doi.org/10.1590/S2317-15372013000100015

SANTORUM, M.; NÓBREGA, L. H. P.; SOUZA, E. G.; SANTOS, D.; BOLLER, W.; MAULI, M. M. Comparison of tests for the analysis of vigor and viability in soybean seeds and their relationship to field emergence. Acta Scientiarum. Agronomy, Maringá, v. 35, n. 1, p. 83-92, 2013.

TAHERI, N.; SEMNANI, S.; ROSHANDEL, G.; NAMJOO, M.; KESHAVARZIAN, H.; CHOGAN, A. G.; KEBRIA, F. G.; JOSHAGNHANI, H. Aflatoxin contamination in wheat flour samples from Golestan Province, Northeast of Iran. Iranian J Publ Health, v. 41, n. 9, p. 42-47, 2012.

TROMBETE, F. M.; MORAES, D. A.; PORTO, Y. D.; SANTOS, T. B.; DIREITO, G. M.; FRAGA, M. E.; SALDANHA, T. Determination of aflatoxins in wheat and wheat by-products intended for human consumption, marketed in Rio de Janeiro, Brazil. Journal of Food and Nutrition Research, Newark, v. 2, n. 10, p. 671-674, 2014. https://doi.org/10.12691/jfnr-2-10-3

TOLEDO, F. F.; MARCOS FILHO, J. Manual seed: Production Technology. = Manual das sementes: tecnologia da produção. Editora Agronômica Ceres, São Paulo, SP, Brazil, 1977.

VIEIRA, R. D. Teste de condutividade elétrica. In: VIEIRA, R. D.; CARVALHO, N. M. Testes de vigor em sementes. Funep, Jaboticabal, SP, Brazil, p. 103-132. 1994. 